droplets help to make the particles more homogeneous. That should enable researchers to choose better precursors and additives that could improve combustion, and yield better-quality end products, says Karsten Wegner, a process engineer and consultant also at ETH Zurich. More and more chemicals companies are asking Wegner for advice on ways to scale up nanoparticle combustionsynthesis processes, he says, and the range of nanomaterials they want to make in large quantities is growing exponentially.

As industry explores the commercial appeal of the technique, researchers are turning to it to create specialized nanoparticles that can be tailored to medical imaging, sensing or toxicity studies. Ian Kennedy, a mechanical engineer at the University of California, Davis, is using combustion to make nanoparticles that contain europium, an exotic and expensive element that phosphoresces strongly. At the MRS meeting, Kennedy described how attaching an antibody to the particles can turn them into detectors that flag up environmental and biological toxicity. "These are exotic materials that haven't been made this way before," says Margaret Wooldridge, a mechanical engineer working on combustion synthesis at the University of Michigan, Ann Arbor.

Exploding droplets are themselves nothing new, says Kennedy - he was studying them in diesel fuel in the 1970s. But imaging techniques like Mädler's will give materials scientists a better understanding of how the explosions affect the properties of the materials produced. "This field is a bridge between combustion research and materials science," says Wooldridge. "It's growing, and you see a lot of younger people coming in." -

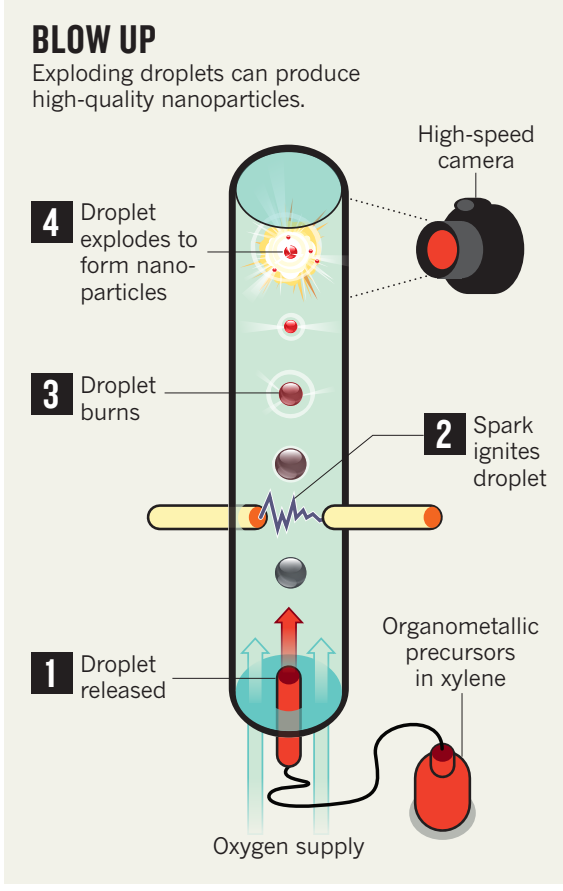

\section{Quiet Texan to head science committee}

\section{BY HELEN SHEN}

$\mathrm{S}$ cience advocates are cautiously hopeful after Lamar Smith, a quiet Texan who is known to be a strong supporter of US innovation, was named as the next chair of the Committee on Science, Space, and Technology in the US House of Representatives. Republican congressional leaders confirmed on 28 November that, in January, Smith will replace Ralph Hall, another Texas Republican, who is stepping down because of a party rule that limits a ranking member's tenure on a House committee to six years.

Smith will become the gatekeeper for much of the science-related legislation that reaches the House floor during the next Congress. Although successful House bills must also pass the Senate before becoming law, Smith - who has served on the committee for 26 years - will be "a key player in setting the agenda", says Scott Pace, director of the Space Policy Institute in Washington DC.

The choice was welcomed by technology advocates such as Keith Grzelak, vicepresident for government relations for the US arm of the Institute of Electrical and Electronics Engineers, based in Washington DC. "He understands the role that science, technology and engineering can play in boosting the economy," says Grzelak.

Smith spearheaded the America Invents Act of 2011, which aimed to simplify patent applications (see Nature 472, 149; 2011). He has also championed legislation to make immigration easier for foreign graduates with science, technology, engineering and mathematics degrees. "We can't have innovation without research and development," Smith said in a statement after his new role was announced.

Like many of his Republican colleagues, Smith has expressed doubts about the reality of anthropogenic global warming and has criticized the media for "a steady pattern of bias on climate change". But his tone has been more moderate than that of his challengers for the chairmanship, Dana
Rohrabacher (Republican, California) and committee vice-chairman Jim Sensenbrenner (Republican, Wisconsin). He is also less outspoken than Hall, who invited several staunch climate-change sceptics to testify before the committee last year. The committee faces a
number of pressing tasks next year, such as reauthorizing NASA - which includes setting the space agency's objectives and also the amount of money the government can appropriate for its operations. Also in need of reauthorization in 2013 will be the America COMPETES act, first passed in 2007. This seeks to enhance US competitiveness in the physical sciences with funding increases to key agencies onal Science Foundation and the Department of Energy's Office of Science.

The fate of America COMPETES will send a statement to the rest of the world about US research and development priorities, says Michael Lubell, director of public affairs at the American Physical Society in Washington DC. "If the signal is going to be the US cannot afford to do this," says Lubell, "I think that's going to be a big mistake." He hopes that Smith, who ultimately voted against reauthorization of America COMPETES in 2010, will support the measure this time and bring on board other Republicans - only 16 of whom supported the final version of the reauthorized act two years ago.

Eddie Bernice Johnson, a Texas representative who is the committee's top-ranking Democrat, hopes that Smith will quiet the partisan posturing on issues such as climate change and the role of the Environmental Protection Agency that marked Hall's chairmanship. "The selection of witnesses has been pretty one-sided," she says.

But fiscal concerns may play the biggest part in shaping Smith's decisions. The country is bracing itself for sweeping federal budget cuts in January unless Republicans and Democrats can reach a compromise on measures to reduce the deficit, and science would not escape the axe. 